\title{
Combination of $\mathrm{CaCO}_{3}$ and $\mathrm{Ca}(\mathrm{OH})_{2}$ as agents for treatment acid mine drainage
}

\author{
Poedji Loekitowati Hariani ${ }^{1, *}$, Salni Salni ${ }^{2}$, and Fahma Riyanti ${ }^{1}$ \\ ${ }^{1}$ Department of Chemistry Faculty of Mathematics and Natural Sciences Sriwijaya University, 30139 Palembang, Indonesia \\ ${ }^{2}$ Department of Biology Faculty of Mathematics and Natural Sciences Sriwijaya University, 30139 Palembang, Indonesia
}

\begin{abstract}
Acid mine drainage (AMD) has characteristic very low $\mathrm{pH}$ solution and containing metal ions in high concentration. This paper presents the use of $\mathrm{CaCO}_{3}, \mathrm{Ca}(\mathrm{OH})_{2}$ and the combination of both to increase the $\mathrm{pH}$ and decreased the concentration of $\mathrm{Fe}$ and $\mathrm{Mn}$ ions for acid mine drainage. The research variables are the effect of reactant dosage, contact time and temperature by batch studies. The AMD before treatment has $\mathrm{pH}$ solution of 3.38, Fe and $\mathrm{Mn}$ ions concentration of 44.6 and $7.19 \mathrm{mg} / \mathrm{L}$, respectively. The dosage of $\mathrm{CaCO}_{3}$ to increased $\mathrm{pH}$ solution about 7.0 was found $2400 \mathrm{mg} / \mathrm{L}$ at contact time 60 minutes and temperature $40{ }^{\circ} \mathrm{C}$. The amount of $\mathrm{Ca}(\mathrm{OH})_{2}$ for the neutralization of AMD solution smaller than $\mathrm{CaCO}_{3}$ is $210 \mathrm{mg} / \mathrm{L}$ at contact time 45 minutes and temperature $40{ }^{\circ} \mathrm{C}$. The combination dosage of $\mathrm{CaCO}_{3} 1000 \mathrm{mg} / \mathrm{L}$ and $\mathrm{Ca}(\mathrm{OH})_{2} 90 \mathrm{mg} / \mathrm{L}$ can increased the $\mathrm{pH}$ of AMD solution to 7.10 and reduction concentration of $\mathrm{Fe}$ to 3.53 and $\mathrm{Mn}$ to $4.51 \mathrm{mg} / \mathrm{L}$. Therefore, the integrated of $\mathrm{CaCO}_{3}$ and $\mathrm{Ca}(\mathrm{OH})_{2}$ has the potential to be applied to treatment acid mine drainage.
\end{abstract}

\section{Introduction}

Acid mine drainage (AMD) is an important problem in the environment and a serious concern in many countries. The AMD contains of heavy metal from the oxidation of sulphidic minerals and producing low of $\mathrm{pH}$ solution. The treatment of AMD must be done on the exhaust into the environment because this substance is harmful to aquatic life at low concentration, not biodegradable and media surroundings. The AMD contains a lot of heavy metal ions such as $\mathrm{Cu}^{2+}, \mathrm{Fe}^{3+}$, $\mathrm{Mn}^{2+}, \mathrm{Zn}^{2+}, \mathrm{Cd}^{2+}$ and $\mathrm{Pb}^{2+}$. The heavy metal ions are not biodegrable and tends to accumulate in the bodies in living organis [1]..

The AMD solution usually is orange colour from precipitation of iron oxide and hydroxide [2]. Characteristic of AMD of each region is different depending on typical mine water for the individual deposits [3]. The characteristic of AMD solution is influenced by several factors such as bacteria, temperature, starting $\mathrm{pH}$ and alternative oxidants like iron or manganese [4].

The treatment of AMD must be efficient and continual [5]. The method is often used for AMD treatment is oxidation, coagulation/flocculation, neutralization and precipitation of metal ions. The oxidants for the AMD such as $\mathrm{Ca}(\mathrm{OCl})_{2}, \mathrm{NaClO}, \mathrm{CaO}_{2}$, $\mathrm{H}_{2} \mathrm{O}_{2}$, whereas coagulands often to treatment of AMD are $\mathrm{Al}_{2}\left(\mathrm{SO}_{4}\right)_{3}, \mathrm{FeSO}_{4}, \mathrm{Fe}_{2}\left(\mathrm{SO}_{4}\right)_{3}, \mathrm{NaAlO}_{2}$ [2].

\footnotetext{
* Corresponding author: pujilukitowati@yahoo.com
}

Some materials can be used for the neutralization process such as $\mathrm{CaCO}_{3}[3,6], \mathrm{Mg}(\mathrm{OH})_{2}$ [7], fly ash [8], $\mathrm{NaOH}$ [9]. The use of $\mathrm{CaCO}_{3}$ for the neutralization process of AMD was patented by the US Geological Survey Leetown Science Center [10]. It has been reported that the $\mathrm{pH}$ of $\mathrm{AMD}$ treatment using $\mathrm{CaCO}_{3}$ (limestone) more economical but slow rate of dissolution with effectiveness $\pm 30 \%$ ) [11]. The other research, effect neutralization of AMD with limestone in the reactor during 48 hours produced an armor coating in the bottom [6]. It causes the decline in the effectiveness of the use of $\mathrm{CaCO}_{3}$. Two step reaction process of limestone with sulfuric acid in the AMD as follows:

$$
\begin{aligned}
& \mathrm{CaCO}_{3}+\mathrm{H}_{2} \mathrm{SO}_{4} \rightarrow \mathrm{CaHSO}_{4}^{+}+\mathrm{HCO}_{3}^{-} \\
& \mathrm{HCO}_{3}^{-}+\mathrm{CaHSO}_{4}^{+} \rightarrow \mathrm{CO}_{2}+\mathrm{H}_{2} \mathrm{O}+\mathrm{CaSO}_{4}
\end{aligned}
$$

At the end of the reaction occurs of precipitated calcium sulfate. The other studies have shown that calcium carbonate to raise the $\mathrm{pH}$ by consuming hydrogen ions and adding alkanity to form bicarbonate ions, according the following reaction: [12]

$\mathrm{CaCO}_{3}+2 \mathrm{H}^{+} \rightarrow \mathrm{Ca}^{2+}+\mathrm{H}_{2} \mathrm{O}+\mathrm{CO}_{2}$
$\mathrm{CaCO}_{3}+\mathrm{H}_{2} \mathrm{CO}_{3} \rightarrow \mathrm{Ca}^{2+}+2 \mathrm{HCO}_{3}^{-}$

The metal ions can be precipitate to form hydroxides or oxyhydrosides. 
Several methods have been developed for treatment of AMD. In this paper, integrated of limestone $\left(\mathrm{CaCO}_{3}\right)$ and hydrated lime $\left(\mathrm{Ca}(\mathrm{OH})_{2}\right)$ was used for neutralization of AMD solution. Effectiveness $\mathrm{Ca}(\mathrm{OH})_{2}$ for AMD treatment three times greater than $\mathrm{CaCO}_{3}$, but the cost of processing using these materials more expensive [11]. Hydrated lime has the ability to raise the $\mathrm{pH}$ quickly and precipitate the metal ions as hydroxide such as manganese at $\mathrm{pH} 9$ to 9.5 . Reaction of $\mathrm{Ca}(\mathrm{OH})_{2}$ with hydrogen ions or metal ios as follow: [13]

$$
\begin{aligned}
& \mathrm{Ca}(\mathrm{OH})_{2}+2 \mathrm{H}^{+} \rightarrow \mathrm{Ca}^{2+}+2 \mathrm{H}_{2} \mathrm{O} \\
& \mathrm{Ca}(\mathrm{OH})_{2}+\mathrm{Me}^{2+} / \mathrm{Me}^{3+} \rightarrow \mathrm{Me}(\mathrm{OH})_{2} / \mathrm{Me}(\mathrm{OH})_{3}+\mathrm{Ca}^{2+}
\end{aligned}
$$
(6)

The other research, the use of $\mathrm{CaCO}_{3}$ on AMD treatment can increase the $\mathrm{pH}$ solution from 2.9 to over 7 at the contact time of 48 hours [6]. Beside that, the addition of $\mathrm{Ca}(\mathrm{OH})_{2}$ do not only neutralized, but also the $\mathrm{OH}^{-}$anionic ions increased the rate of speciation with reaction to metal ions and increased the $\mathrm{pH}$ of AMD. $\mathrm{CaCO}_{3}$ and $\mathrm{Ca}(\mathrm{OH})_{2}$ can also destabilize the hydrolysis of acid mine drainage so that the value of TSS decrease [14].

At present, the combination of $\mathrm{CaCO}_{3}$ and $\mathrm{Ca}(\mathrm{OH})_{2}$ to treatment of $\mathrm{AMD}_{2}$ is expected to increase the $\mathrm{pH}$ and reduction the heavy metal ions at the faster contact time. $\mathrm{Ca}(\mathrm{OH})_{2}$ has a greater solubility than $\mathrm{CaCO}_{3}$ are 1850 and $14 \mathrm{mg} / \mathrm{L}$, respectively [7]. The parameters of studied are the effect of reactant dosage, contact time and temperature by batch studies.

\section{Experimental details}

\subsubsection{Materials}

The reagents such as $\mathrm{CaCO}_{3}, \mathrm{Ca}(\mathrm{OH})_{2}$ were analytical grade by Merck and all solution were prepare with deionized water. Acid mine drainage collected from a mine in Tanjung Enim, South Sumatera, Indonesia.

\subsubsection{Effect of dosage, contact time and temperature}

The effect of dosage was added of $\mathrm{CaCO}_{3}$ and $\mathrm{Ca}(\mathrm{OH})_{2}$ to $1 \mathrm{~L}$ of AMD solution at constant stiring $(120 \mathrm{rpm})$ at room temperature for 60 minutes. The amount of $\mathrm{CaCO}_{3}$ was added from 100-2500 mg/L (interval $100 \mathrm{mg}$ ) and $\mathrm{Ca}(\mathrm{OH})_{2} \quad 10-240 \mathrm{mg} / \mathrm{L}$ (interval $10 \mathrm{mg}$ ). The data of effect contact time obtained from 0-100 minutes with interval 5 minutes. The effect of the temperature was performed using thermostatic water bath at temperature of $30-90{ }^{\circ} \mathrm{C}$. Data is the observed $\mathrm{pH}$ of the solution. The $\mathrm{pH}$ solution is obtained using $\mathrm{pH}$ meter Orion star A2111.

\subsubsection{Neutralization of AMD using combination $\mathrm{CaCO}_{3}$ and $\mathrm{Ca}(\mathrm{OH})_{2}$}

For this purpose $\mathrm{CaCO}_{3}$ and $\mathrm{Ca}(\mathrm{OH})_{2}$ were added to $1 \mathrm{~L}$ of AMD. The amount of $\mathrm{CaCO}_{3} 1000 \mathrm{mg}$ while the $\mathrm{Ca}(\mathrm{OH})_{2}$ in the range $10-120 \mathrm{mg}$ (interval $10 \mathrm{mg}$ ) with contact time and temperature using the latest result of previous studies. Determination of metal ions ( $\mathrm{Fe}$ and $\mathrm{Mn}$ ) in AMD before and after treatment were determined using Atomic Absorption Spectroscopy Shimadzu AA 7000 with atomization by $\mathrm{N}_{2} \mathrm{O}$-acetilene flame. The wave number for obtaining $\mathrm{Fe}$ and $\mathrm{Mn}$ ions at 248.3 and $279.8 \mathrm{~nm}$, respectively.

\section{Result and discussion}

There are two technologies for treatment of acid mine drainage (AMD), these are active treatment and passive treatment processes. The active treatment method is the addition of chemicals to raise the $\mathrm{pH}$ and precipitate the metal ions. The active treatment using chemical reagents. This method is very effective for the treatment of AMD. The passive treatment includes aerobic and anaerobic wetland. This method is natural process.

In traditional treatment of $\mathrm{AMD}, \mathrm{CaCO}_{3}$ has been used for neutralization of AMD in many countries. There used in anoxic limestone drain and open limestone channel [9]. In this study, the combination of $\mathrm{CaCO}_{3}$ and $\mathrm{Ca}(\mathrm{OH})_{2}$ to treatment of AMD was evaluated. Before integrating of both, investigated the optimum conditions of treatment in each material includes the effect of dosage of $\mathrm{CaCO}_{3}$ and $\mathrm{Ca}(\mathrm{OH})_{2}$, contact time and temperature.

Neutralization of AMD using $\mathrm{CaCO}_{3}$ and $\mathrm{Ca}(\mathrm{OH})_{2}$ are presented in Fig 1. and Fig 2. The AMD solution has initial $\mathrm{pH}$ of 3.38. The AMD is classified as types of 1 that has $\mathrm{pH}$ solution very lower. In the AMD, pyrite is oxidized to soluble iron and sulphuric acid as follows : [15]

$2 \mathrm{FeS}_{2}+7 \mathrm{O}_{2}+2 \mathrm{H}_{2} \mathrm{O} \rightarrow 2 \mathrm{Fe}^{2+}+4 \mathrm{SO}_{4}{ }^{2-}+4 \mathrm{H}^{+}$

$\mathrm{Fe}^{2+}$ is oxidaxed to $\mathrm{Fe}^{3+}$ by oxygen and hydrogen and oxidation of sulfure by Thiobacillus and Ferroplasma bacteria.

The oxidation process is influenced by $\mathrm{pH}$ solution, this reaction occurs fast at low $\mathrm{pH}(<4)$. Ferrous hydroxide formed is namely yellow boy. $[5,16]$

$2 \mathrm{Fe}^{2+}+7 \mathrm{O}_{2}+2 \mathrm{H}_{2} \mathrm{O} \rightarrow 4 \mathrm{Fe}^{3+}+4 \mathrm{H}_{2} \mathrm{O}$

$4 \mathrm{Fe}^{3+}+12 \mathrm{H}_{2} \mathrm{O} \rightarrow 4 \mathrm{Fe}(\mathrm{OH})_{3}+12 \mathrm{H}^{+}$ (9)

The result obtained that the increased dosage of $\mathrm{CaCO}_{3}$ and $\mathrm{Ca}(\mathrm{OH})_{2}$ increased of $\mathrm{pH}$ and reached at $\mathrm{pH}$ 7 on the addition $\mathrm{CaCO}_{3}$ of $2400 \mathrm{mg}$ while $\mathrm{Ca}(\mathrm{OH})_{2}$ of 
$210 \mathrm{mg}$. $\mathrm{Ca}(\mathrm{OH})_{2}$ has the ability to increase the $\mathrm{pH}$ solution of $\mathrm{AMD}$ better than $\mathrm{CaCO}_{3}$. The positive correlation that fact with increasing dosage of neutralization agents, more hydrogen ions can be neutralized using $\mathrm{CaCO}_{3}$ and $\mathrm{Ca}(\mathrm{OH})_{2}$.

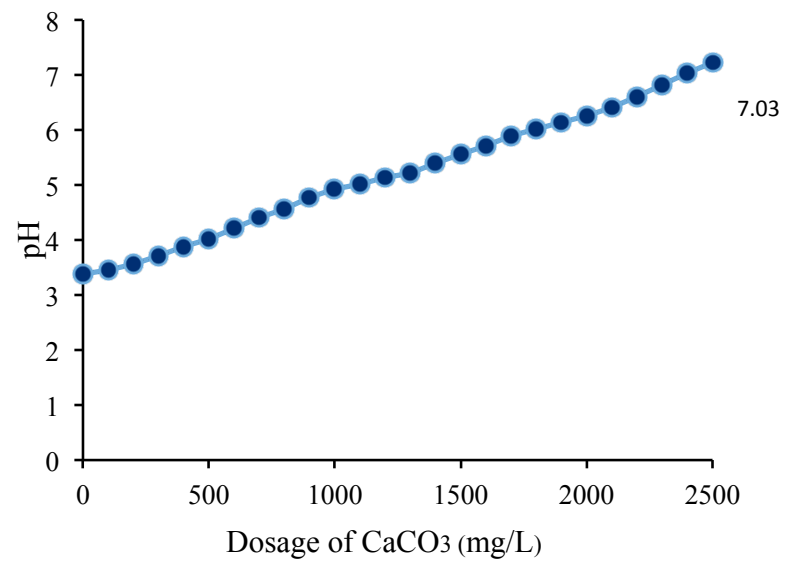

Fig. 1. Effect of dosage $\mathrm{CaCO}_{3}$ for $\mathrm{pH}$ solution

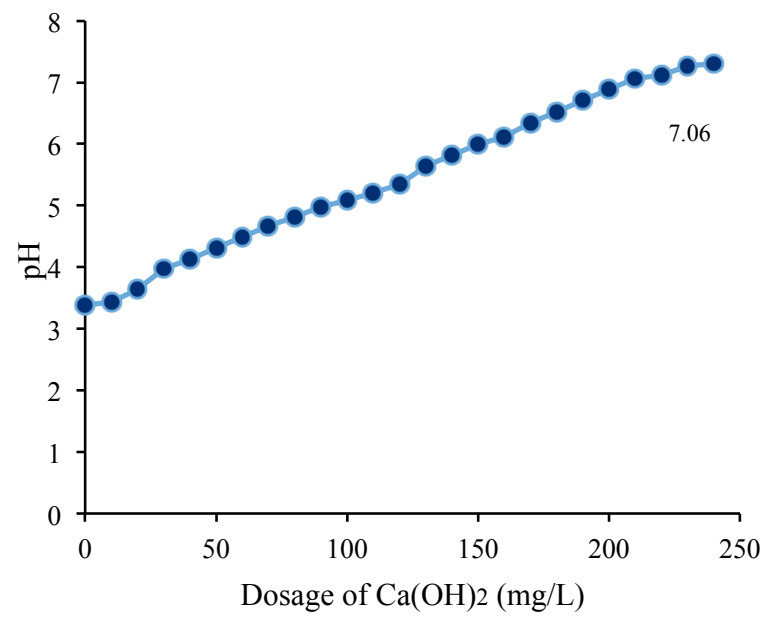

Fig. 2. Effect of dosage $\mathrm{Ca}(\mathrm{OH})_{2}$ for $\mathrm{pH}$ solution

The both of agents have the same acid equivalent is 2 but $\mathrm{Ca}(\mathrm{OH})_{2}$ has an efficiency factor of 0.8 higher than $\mathrm{CaCO}_{3}$ of 0.4 [17]. Efficiency factor is an empirical estimate for neutralizing acidity. Besides than, $\mathrm{Ca}(\mathrm{OH})_{2}$ is a strong alkaline has a neutralization efficiency of 90 $\%$ greater than $\mathrm{CaCO}_{3}$ only $30 \%$ [11]. The alkaline necessary to raise the $\mathrm{pH}$ solution and produce hydroxide to precipated with metal ions.

Table 1 shows some of the materials used to raise the $\mathrm{pH}$ solution of AMD. Compared to the data in table, the results of this research requires fewer doses to increase $\mathrm{pH}$ of AMD. The type and dosage of materials have effect to the increase of $\mathrm{pH}$ solution.

Figure 3 showed effect contact time of $\mathrm{CaCO}_{3}$ and $\mathrm{Ca}(\mathrm{OH})_{2}$ on the neutralization of AMD. The data obtained that the equilibrium time required for the neutralization was almost 60 minutes for $\mathrm{CaCO}_{3}$ and 45 minutes for $\mathrm{Ca}(\mathrm{OH})_{2}$.

Table 1. The materials to treatment of AMD

\begin{tabular}{lccc}
\hline Materials & Dosage & \multicolumn{2}{c}{$\begin{array}{c}\mathrm{pH} \text { of Acid mine } \\
\text { drainage }\end{array}$} \\
\cline { 3 - 4 } & & $\begin{array}{c}\text { Initial } \\
\mathrm{pH}\end{array}$ & $\begin{array}{c}\text { Final } \\
\mathrm{pH}\end{array}$ \\
\hline $\mathrm{Mg}(\mathrm{OH})_{2}[7]$ & $0.25 \mathrm{~g} / \mathrm{L}$ & 3.4 & 8.3 \\
$\mathrm{Ba}(\mathrm{OH})_{2} \cdot 8 \mathrm{H}_{2} \mathrm{O}[7]$ & $7.35 \mathrm{~g} / \mathrm{L}$ & 3.4 & 12 \\
Fly ash [8] & AMD:Fly & 2.7 & 11.5 \\
& ash (2:1) & & \\
Fly ash [8] & AMD:Fly & 2.7 & 11.5 \\
& ash (1:1) & & \\
Fly ash [8] & AMD:Fly & 2.7 & 9.5 \\
& ash (3:1) & & \\
Limestone [6] & - & 2.9 & 6.5 \\
Bentonite [18] & $1 \mathrm{~g} / \mathrm{L}$ & 2.7 & 7.5 \\
\hline
\end{tabular}

The contact time affect the number of hydrogen ions that can be neutralized by chemical agents. The longer the contact time so the more hydrogen ions that can be neutralized. From the result, the neutralization using $\mathrm{Ca}(\mathrm{OH})_{2}$ faster than $\mathrm{CaCO}_{3}$. In this work indicated that an increase in contact time resulted in increased of $\mathrm{pH}$ solution. After the equilibrium time, the $\mathrm{pH}$ relatively constant at $\mathrm{pH}$ 7. It is clear that the $\mathrm{pH}$ value dependence of contact time. The longer of the contact time, the more neutralization process. Furthermore, $\mathrm{pH}$ relatively constant at about $\mathrm{pH} 7$ for a limited amount of reagents.

To compare the other research, the optimal dosage to reach at $\mathrm{pH} 7$ on acid mine water in the locality of Jiří Mine in the Sokolov Region is $150 \mathrm{mg} / \mathrm{L}$ of $\mathrm{Ca}(\mathrm{OH})_{2}$ with contact time 30 minutes [3]. The reduction of sulfate from AMD also dependent dosage of $\mathrm{CaCO}_{3}$ and $\mathrm{Ca}(\mathrm{OH})_{2}$. The research indicated that the relationship between sulfate solubilization and $\mathrm{pH}$ was direct and linear [19].

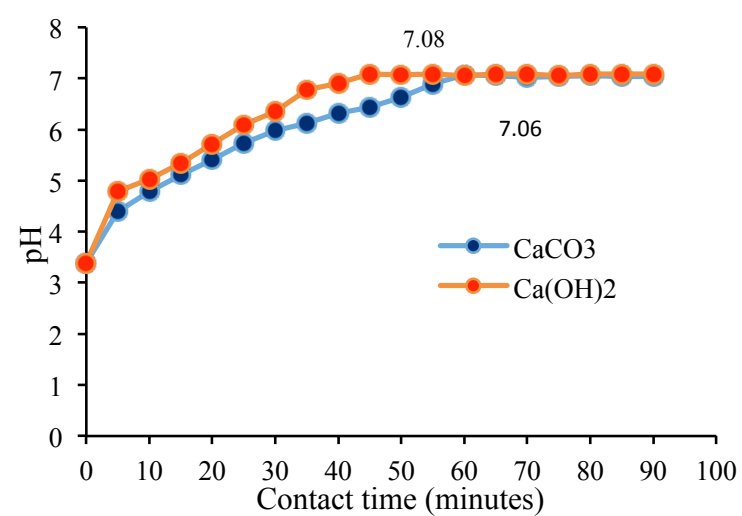

Fig. 3. Effect of contact time for $\mathrm{Ph}$ solution

The effect of temperature for AMD neutralization is presented in Fig 4. On evaluating the result, it was clear 
that an increase of $\mathrm{pH}$ at the temperature $20-40{ }^{\circ} \mathrm{C}$, and then the $\mathrm{pH}$ decreased at higher temperature. The solubility indicated the maximum concentration of substance that can be dissolved at solution (ussulaly at room temperature). Beside $\mathrm{pH}$ solution, the solubility of compound is also dependent by temperature. The increase of temperature so the greater solubility of compounds.

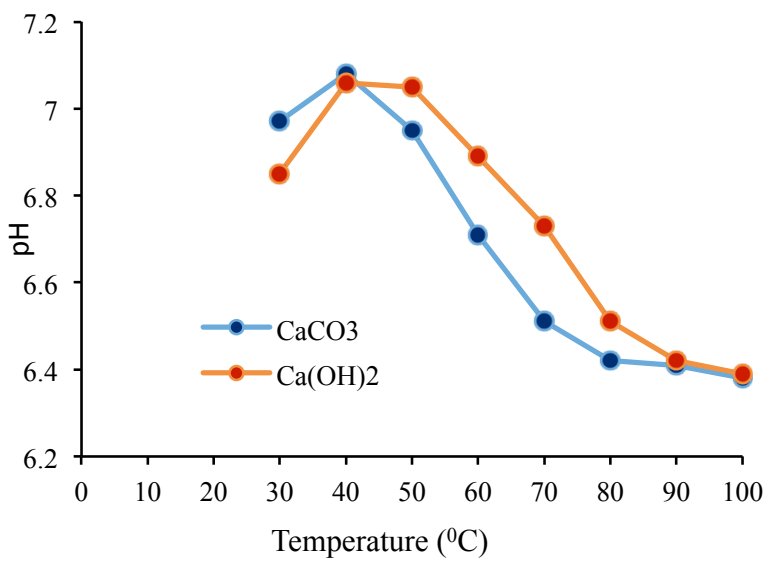

Fig.4. Effect of temperature for $\mathrm{pH}$ solution

The chemical reagents of $\mathrm{CaCO}_{3}$ and $\mathrm{Ca}(\mathrm{OH})_{2}$ have the same pattern of obtained $\mathrm{pH} 7$ at temperature $40{ }^{\circ} \mathrm{C}$. If the temperature is increased, the average kinetics also increases, it destabilized the solid state and thus the dissolve of the precipitate. This causes solubility of hydrogen ions and then the $\mathrm{pH}$ solution is decreased. The same result observed the influence of temperature for neutralization of AMD solution using $\mathrm{NaOH}$. The optimum temperature at $20{ }^{\circ} \mathrm{C}$, there was no change in $\mathrm{pH}$ at temperature 40 and $60{ }^{\circ} \mathrm{C}$. The $\mathrm{pH}$ dropped to 2.2 at temperature $90{ }^{0} \mathrm{C}$ [9].

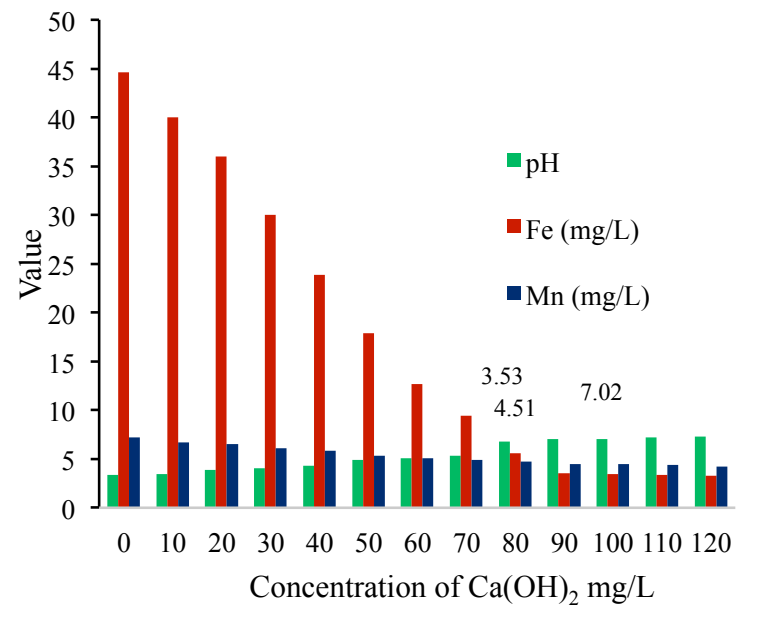

Fig. 5. Combination of $\mathrm{CaCO}_{3}$ with $\mathrm{Ca}(\mathrm{OH})_{2}$ to treatment of AMD solution
The combined of $\mathrm{CaCO}_{3}$ and $\mathrm{Ca}(\mathrm{OH})_{2}$ is expected to reduce the dosage of $\mathrm{CaCO}_{3}$ and improve efficiency process and economical. The concentration of $\mathrm{Fe}$ and $\mathrm{Mn}$ ions in AMD solution during the addition of 1000 $\mathrm{mg} / \mathrm{L} \mathrm{CaCO}_{3}$ and variation dosage of $\mathrm{Ca}(\mathrm{OH})_{2}$ from 10 $120 \mathrm{mg} / \mathrm{L}$ showed in Fig 5.

The process at contact time 45 minutes and temperature $40{ }^{0} \mathrm{C}$. The AMD have contain of $\mathrm{Fe}$ is $44.6 \mathrm{mg} / \mathrm{L}$ while the $\mathrm{Mn}$ is $7.19 \mathrm{mg} / \mathrm{L}$. Characteristic of AMD solution exceeds of acid mine drainage quality standard. The maximum of Fe is $7 \mathrm{mg} / \mathrm{L}, \mathrm{Mn}$ is $4 \mathrm{mg} / \mathrm{L}$ and $\mathrm{pH}$ solution in the range 6-9 [20]. We can see that after neutralization using $\mathrm{CaCO}_{3}$ and $\mathrm{Ca}(\mathrm{OH})_{2}$ was reached $\mathrm{Fe}$ and $\mathrm{Mn}$ ions of 3.53 and $4.51 \mathrm{mg} / \mathrm{L}$, respectively.

The $\mathrm{pH}$ solution increased from 3.38 to 7.02 . The effectively decrease of $\mathrm{Fe}$ and $\mathrm{Mn}$ ions were 92.42 and $37.27 \%$. The effectivity to removal Fe ions from AMD greater than $\mathrm{Mn}$ ions. The oxidixed and precipitation of Fe ions about at $\mathrm{pH} 7.0$ while $\mathrm{Mn}$ ions at higher $\mathrm{pH}$ is 8 . The other studies shows that $\mathrm{CaCO}_{3}$ and $\mathrm{Ca}(\mathrm{OH})_{2}$ effectif to reduced TSS by mechanism coagulation and floculation [21]. The study also investigated interaction double layer metal ions on both reagents of the aquacolloids.

The use of bottom ash, bentonite and fly ash to reduce the concentration of iron ions obtained at the optimum weight of $3,4,4 \mathrm{~g}$ in $100 \mathrm{~mL}$ of AMD solution, respectively [18]. In this study, has a smaller dosage than the result. Another study shows that adsorption capacity for adsorption of $\mathrm{Mn}$ ions in AMD is $6.03 \mathrm{mg} / \mathrm{g}$ using bone char [22].

The AMD solution is very complex, there is competition between the metal ions to form precipitate. The metal ions form precipitates depending value of Solubility Product Constant (KSP). The Ksp is the equilibrium constant, indicated that saturated solutions of ionic dissolving in an aqueous. The metal ions have small solubility product constants will be precipitated first. Example, $\mathrm{Ksp} \mathrm{Fe}(\mathrm{OH})_{3}=6.10^{-38}$ smaller than $\mathrm{Ksp}$ $\mathrm{Mn}(\mathrm{OH})_{2}=2.10^{-13}$, so $\mathrm{Fe}$ ions to form precipitate earlier than Mn ions [23].

\section{Conclusions}

The combination of $\mathrm{CaCO}_{3}$ and $\mathrm{Ca}(\mathrm{OH})_{2}$ can be used for neutralization and reduce metal ions on acid mine drainage (AMD) solution. Integrated of both with a dosage of $\mathrm{CaCO}_{3} 1000 \mathrm{mg} / \mathrm{L}$ and $\mathrm{Ca}(\mathrm{OH})_{2} 90 \mathrm{mg} / \mathrm{L}$ can raise the $\mathrm{pH}$ solution from 3.38 to 7.02 and decrease of $\mathrm{Fe}$ and $\mathrm{Mn}$ ions with efficiency 92.42 and $37.27 \%$, respectively. In this study show that combination of $\mathrm{CaCO}_{3}$ and $\mathrm{Ca}(\mathrm{OH})_{2}$ an effectif to treatment of AMD.

This research was supported by The Directorate General of Technology Research and Higher Education (Ristekdikti), Republic Indonesia with "Unggulan Perguruan Tinggi Programme in 2016, Sriwijaya University". 


\section{References}

1. N. Moreno, X. Querol, X., C. Ayora. Environm. Sci. and Tech., 35, 3526-3534 (2001)

2. T. Motsi. Thesis. University of Birmingham, United Kingdom (2010)

3. D. Kirby. Dissertation. Marshall University, Virginia (2014)

4. S. Heviankova, I. Bestova, M. Kyncl, L. Simkova, M. Zechner. J. of the Polish Mineral Eng. Soc., 159-166 (2013)

5. C. Zipper, J. Skousen, C. Jage. Virginia Cooperative Extension. Powell River Project, 1-14 (2011)

6. J.M. Hammarstrom, P.L. Sibrell, H.E. Belkin, Appl. Geochem., 18, 1705-1721 (2003)

7. V. Bologo, J.P. Maree, C.M. Zwinovanda. Proceeding of the International Mine water Conference, Pretoria, South Africa, 372-380 (2009)

8. V.R.K. Vadapalli, M.J. Klink, O. Etchebers, L.F. Petrik, W. Gitari, R.A. White, D. Key, E. Iwuoha, S AFR J SCL, 104, 317-322 (2008)

9. E. Michalkova, M. Schwarz, P. Pulisova, B. Masa, P. Sudovsky, Pol. J. Environt Stud., 22(4), 11111118 (2013)

10. B.J. Watten. US patent No. 5.914.046. US Department of Commerce, Washington DC, (1999)

11. J. Skousen. T. Hilton, B. Faulkner, American Society of Agronomy and the American Society for Surface Mining and Reclamation, (1997)
12. Y. Paul, S.A. Banwart, Hedin, S. Robert, Kluwer Academic Press, Netherlands, (2002)

13. B. Lottermoser, Springer Berlin Heilderberg, London-New York, (2010)

14. I.O. Ntwampe, F.B. Waanders, J.R. Bunt, J. Chem. Eng. Mater. Sci., 6(3), 15-33 (2015)

15. C.N. Sawyer, Mc Catty, P.L., G.F. Parkin. Mc Graww Hill International Editions, (1994)

16. H.L. Yadav, A. Jamal, Intern. J. New Tech. Sci. Eng., 2(3), 77-84 (2015)

17. C.A. Cravotta, D.L. Parkhurst, B. Means, R. Mc Kenzie, W. Arthur. Proceeding of National Meeting of The American Society of Mining and Reclamation, Pittsburgh, PA Bridging Reclamation, Scince and the Community, 1413-1436 (2010)

18. E.O. Orakwue, V. Asokbunyarat, E.R. Rene, P.N.L. Lens, A. Annachhatre, Water Air Soil Pollut, 227(74), 1-12 (2016)

19. S. Rose, W. C. Elliot. Appl. Geochem., 15, 27-34 (2000)

20. Governor Regulation in South Sumatera No 8 (2012).

21. I.O. Ntwampe, F.B. Waanders, J.R. Bunt, J. Chem. Eng. Mater. Sci., 6(3), 34-51 (2015)

22. D.C. Sicupira, T.T. Silva, A.C.Q. Ladeira, M.B. Mansur, Brazilian J. Chem. Eng., 32(02), 577-584 (2015)

23. W.B. Euler, L.J. Kirschenbaum, B. Ruekberg, Jour. Chem. Ed., 77(8), 1039-1040 